\title{
Drug Delivery System
} original article

\section{単離腫湯灌流実験系を利用した薬物移行特性 評価法の開発}

\author{
井本博文 - 大河内一宏 - 高倉喜信 - 橋田 充 - 瀬崎 仁*
}

Development of evaluation method for drug disposition in tumor using tissue-isolated tumor perfusion system

New method to evaluate drug disposition characteristics in tumor was developed employing rat tissue-isolated Walker 256 carcinosarcoma perfusion system. Mitomycin C and its lipophilic and macromolecular prodrugs used as a prototype of targeting DDS were administered from the arterial side by bolus injection or constant infusion. By applying moment analysis and so on, disposition characteristics of these drugs in tumor were elucidated and discussed in relation to their physicochemical properties.

These experimental system was thus suggested to be useful in evaluating drug disposition in tumor.

Hirofumi Imoto $\cdot$ Kazuhiro Ohkouchi . Yoshinobu Takakura $\cdot$ Mitsuru Hashida .

Hitoshi Sezaki*

key words : disposition characteristics, tissue-isolated tumor preparation, perfusion experiment, moment theory

ドラッグデリパリーシステム(DDS)の開発に おいては，素材や製剤手法など調製にかかわる方 法論の開発とともに，作成されたシステムが設計 されたとおりの機能性を有するかと゚うかを評価し うる方法論の確立が重要な役割を果たす。とりわ け，標的作用部位への選択的送達を目的とした ターゲティング型 DDS の開発においては, 薬物 の標的への移行動態を定量的に把握し, システム の物理化学的特性と関連づけて解析することを可 能にする実験解析系の開発が不可欠の条件になる ものと考えられる.

筆者らの研究グループでは,こうした観点から，

\footnotetext{
* Department of Basic Pharmaceutics, Faculty of Pharmaceutical Sciences, Kyoto University 京都大学薬学部 薬剂学教室
}

抗癌剤を対象にしたターゲティング型 DDS の開 発1 3) と並行して, 癌病巣における薬物移行動態の 評価解析系の開発を行ってきた。すでに，担癌マ ウスを用いた全身投与系における癌病巣への分布 特性の評価解析法 ${ }^{4}$, リンパ指向性 DDS の評価 法5), あるいはVX2 担癌家鬼下肢灌流実験系を利

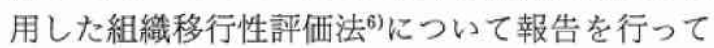
いるが, 今回, ラット単離腫瘍組織標本に対する 血管灌流実験系を利用して, 腫瘍組織における薬 物動態を解析する方法を開発したので報告する。

ここで利用した単離腫瘍組織標本は, Gullino らによって 1961 年に報告されたもので7), 現在に 至るまで彼や共同研究者の Jain らによって腫瘍 組織の生理学的特性の研究に利用されている ${ }^{8)}$. 筆者らは,この実験系では家鬼下肢を用いる系な どとは異なり, 完全に単離された状態で腫瘍病采 の灌流が行える点に注目し，同時に，筆者らがす でに理論誘導を行った indicator dilution 実験に 対するモーメント解析法 ${ }^{9}$ と組み合わせることに より, 腫瘍病巣における薬物動態の解析を可能に した.

\section{材料と方法}

\section{(1) 単離腫瘍標本の作成}

Wistar 系雌性ラット ( 6 週齢) の左腹部を切開 し, 左卵巣周囲脂肪組織に約 $2 \mathrm{~mm}$ 角に切った Walker 256 癌肉腫切片を移植後, 脂肪組織全体 を薄いプラスチックフィルムで包み, 周囲と隔離 した状態で腹部皮下空間に固定し, 腫瘍を成長さ せた. 1 週間後にプラスチックフィルムを交換し， 腫瘍が約 $2 \mathrm{~cm}$ 径に成長した移植後 2 週間の時点 で灌流実験を行った。

(2) 灌流実験手技

腫瘍移植ラットを開腹し，左腎動静脈付近より 


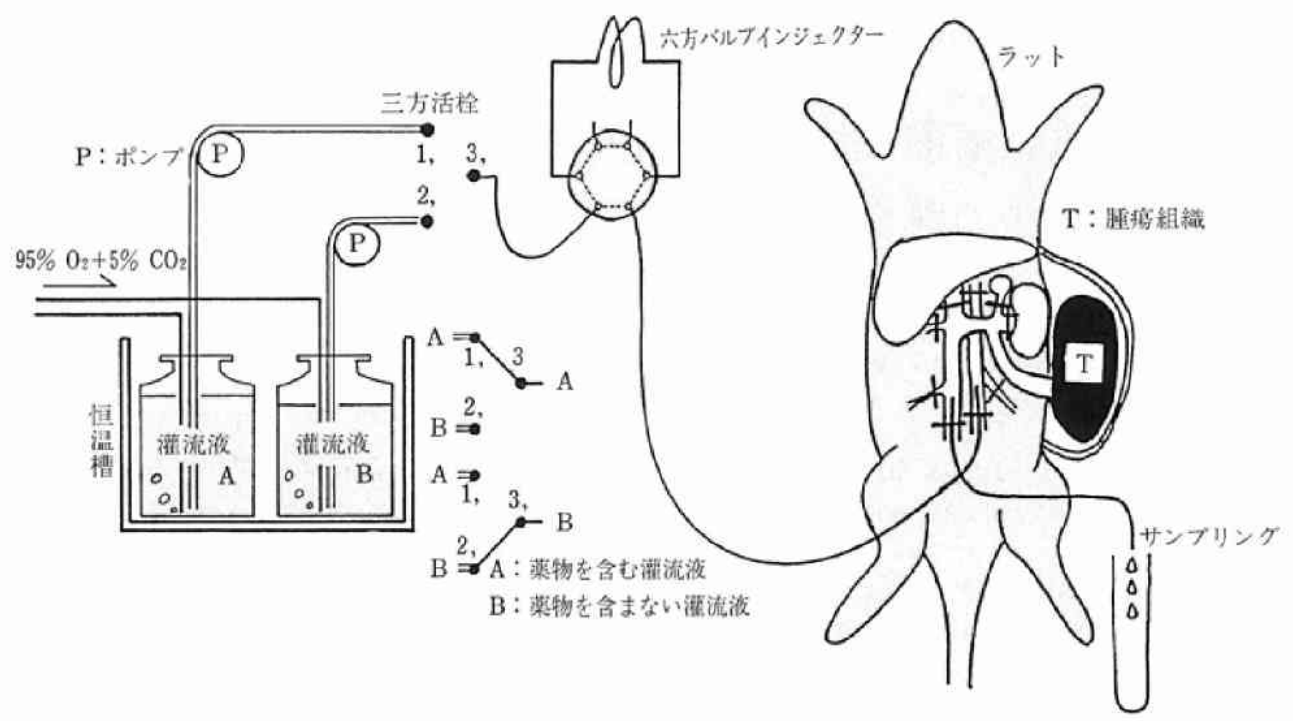

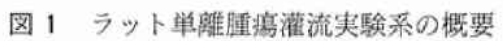

分岐している腫湭部へ向かう血管系を残して, 左 腎および副腎動静脈，下大動静脈の心臟側と側腹 血行路を結禁した。ただちに，カテーテルを下大 動脈つついて下大静脈の末梢側に插入し, 動脈側 より注入した灌流液が，腫瘍組織中を経て静脈側 より流出することを確認した，灌流液には $90 \%$ $\mathrm{O}_{2}-5 \% \mathrm{CO}_{2}$ で平衡化した $4.7 \%$ ウシ血清アルブ ミン含有タイロード液を用い, 流速は $0.8 \mathrm{ml} / \mathrm{min}$ に設定した。

\section{（3）薬物の腫瘍組織内動態解析法}

薬物の組織移行性評価法は, 大きく, 動脈側に 瞬時投与したあと静脈側に流出する薬物の希釈曲 線を解析する indicator dilution 実験 A と, 一定 濃度の薬物を動脈側より定速で供給し, 静脈側へ の流出液あるいは組織内濃度の変化を観察する定 速注入実験Bにわけられる。それぞれの実験方法 に対し，実験結果から組織内動態を示すパラメー ターを誘導する解析法が存在するが, 得られる情 報の内容が異なるので, 評価対象薬物 (DDS) の特 性, 実騟精度などに応じた選択が必要である。

実験 A：瞬時投与実験 (indicator dilution 実 験)

瞬時投与は，濩流回路に六方バルブインジェク ターを組み込み，これを用いて薬物を矩形注入す ることにより行った(図 1). 各標本に対して, 評 価対象薬物と血管内のみを通過し, 組織側へ移行
しない標準物質 (vascular reference substance, VRS) であるエパンスブルー標識ウシ血清アルブ ミン(EB/BSA)を注入し，それぞれの dilution curveを得た. 得られた dilution curve にモーメ ント解析を適用し, 曲線下面積(AUC) と平均通過 時間(MTT)のようなモーメントパラメーター (moment parameter)を求め, つづいて, 分布・ 消失の各側面から局所薬物動態を表す分布容積, 回収率などの高次のパラメーター(disposition parameter)を導いだ9.

\section{実験 B：定速注入実験}

一定濃度の薬物を含む灌流液を 3 時間連続して 灌流した後灌流液を切り替え, 血管内に残留した 薬物を 5 分間洗い流し，この間の静脈側流出液中 の薬物濃度を定量した。 また, 灌流終了後, 組織 中に蓄積した薬物濃度を定量した，組織中薬物濃 度を, この間の灌流液中薬物濃度の AUC で除す ことにより，組織取り込み速度を計算した。

\section{(4) 評価薬物}

本実験系の DDS 評価における有用性を明らか にするために, 筆者らの研究室で開発したマイト マイシン $\mathrm{C}(\mathrm{MMC})$ の脂溶性低分子プロドラッグ と高分子化プロドラッグ(図 2)を抗癌剂 DDS の プロトタイプとし，それぞれの腫瘍組織移行性を 評価した， MMCの脂溶性プロドラッグとして選 んだ pentyloxycarbonyl-MMC(pentyl-MMC) 
<smiles>COC12CNC3CN(C4=C1C(=O)C(N)=C(C)C4=O)C2C3N</smiles>

MMC

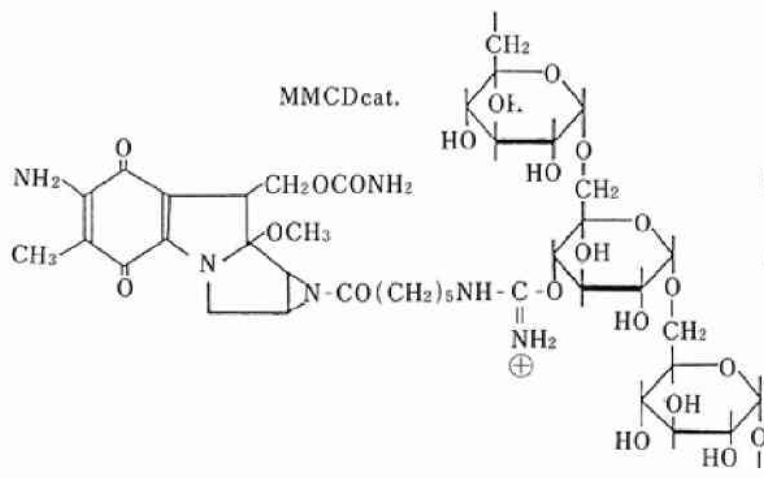<smiles>CCC(=O)N1C2CN3C4=C(C(=O)C(N)=C(C)C4=O)C(CC3C)C2(OC)C1C(N)=O</smiles>

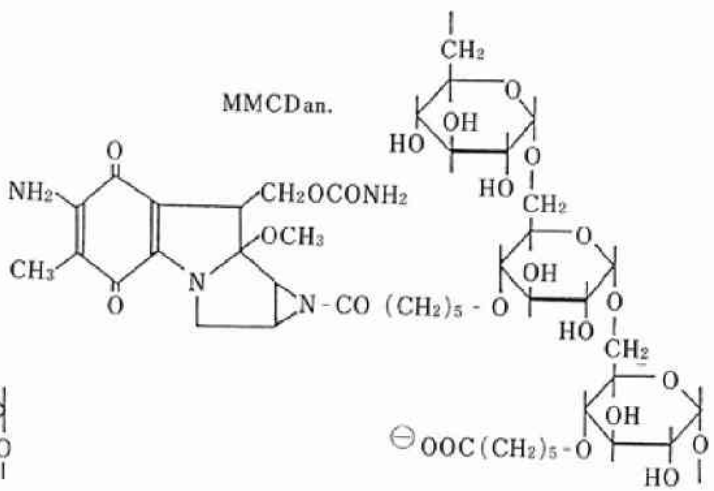

図 2 評価対象としたマイトマイシンCプロドラッグの化学構造

は, $\mathrm{MMC}$ の活性発現基であるアジリジン基に脂 溶性側鎖を導入したもので,オクタノール/水間分 配係数が 0.41 (MMC)から 279.2 (pentyl-MMC) へと増大し高い脂溶性を有している。

一方, 高分子化プロドラッグとしては, MMC を 平均分子量 7 万の dextranに結合させ, 正および 負電荷を付与した MMC-dextran 結合体 (MMCDcat.), (MMCDan.)を選んだが, これらは

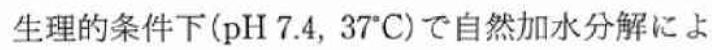
D MMC を徐放(放出半減期 $24 \sim 35 \mathrm{hr}$ ) すること が確かめられている。

\section{結果と考察}

移植した腫場の成長とともに，移植部位である 脂肪組織は, 平均 8 グラムの腫瘍細胞により構成 された単灕腫瘍組織となり, それに伴って, 卵巣 と脂肪組織に血流を供給していた 1 組の動静脈は 腫湯組織への血流の供給にその機能を転じた．形 態的には特に腫瘍組織からの血流が戻る静脈の拡 張が顕著であった.

このように作成した単離腫㿋組織が 1 対の動静 脈により栄羡支配を受けることにより, 正常組織 を含ますに、腫瘍病巣のみを選択的に灌流するこ とが可能となった.

そこでつぎに，本実験系の薬物移行動態評価に

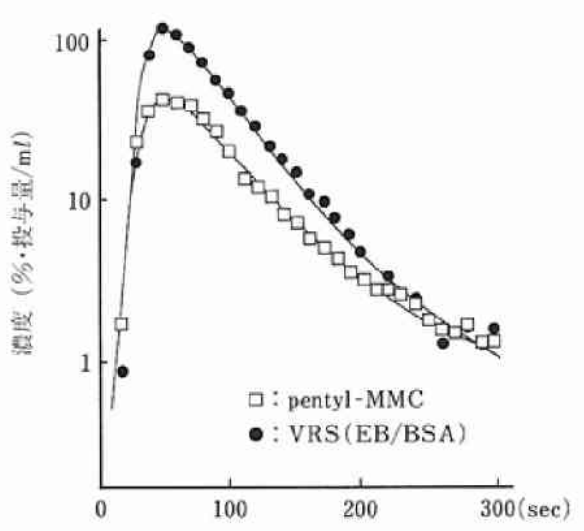

图 3 penty-MMC 瞬時投与実馀により 得られた典型的な dilution curve

おける有用性を明らかにするために, pentyl一 MMC と MMC の移行動態を, 瞬時投与実験によ り検討した. pentyl-MMC を動脈側より矩形で投 与することにより得られた dilution curve(図 3 ) は, 同一の標本から得られた VRS の dilution curve と比較して, 最高濃度の低下と後半の濃度 低下の遅延化を特徴とし, 組織への取り込みと血 管灌流液へのもどりがこれらに反映されているも のと推察された.

また, MMCについても同様に dilution curve が得られた。 そこで, dilution curveより表 1 に 
表 1 dilution curve をモーメント解折して算出した パラメーター

\begin{tabular}{|c|c|c|c|}
\hline & pentyl-MMC & MMC & VRS \\
\hline $\begin{array}{l}\mathrm{AUC} \\
(\% \cdot \text { 投与量・秒 } / \mathrm{ml})\end{array}$ & 4526 & 5678 & 8266 \\
\hline $\begin{array}{l}\text { 平均通過時間：MTT } \\
\text { (秒) }\end{array}$ & 68.6 & 72.1 & 58.3 \\
\hline 回収率：F & 0.55 & 0.69 & 1 \\
\hline $\begin{array}{l}\text { 分布容積 } \\
(\mathrm{ml} / \mathrm{g})\end{array}$ & 0.197 & 0.172 & 0.092 \\
\hline $\begin{array}{l}\text { CLint. u } \\
(\mathrm{ml} / \mathrm{min} / \mathrm{g})\end{array}$ & 0.465 & 0.0541 & - \\
\hline
\end{tabular}

示すようにモーメントパラメーターと局所動態を あらわすパラメーターを算出し, 移行現象の定量 化を図った. VRS と比較して pentyl-MMC, MMC では，AUC の低下，平均通過時間の延長 が認められ，また，分布容積もおのおの VRSの 2.1 倍と 1.9 倍に増大し, 両薬物が血管外組織へ 移行していることも示唆された. pentyl-MMC と MMC とを比較すると, VRS の AUC に対する $\mathrm{MMC}$ の AUC の比としてあらわされる回収率 F において, MMC は0.69であったのに対し, pentyl-MMC では 0.55 となり, 組織に取り込ま れる割合は pentyl-MMC のほうが大きいことが 示唆された。また，蛋白質非結合型楽物の組織に おける処理の受けやすさを示す CLint. u の值で みると, pentyl-MMC が MMC の8.6 倍となり, 前者が組織に効率よく取り込まれ薬効を発現する ことが示唆された。

一方, 今回の実験系で得られるVRS の分布容 積 $(0.092 \mathrm{ml} / \mathrm{g})$ は組織単位重量当りの血管内容積 に相当するが，この值は Walker 256 癌肉腫につ いての他の方法で求められた值ともほほ一致し, 本実験系が腫湟標本の特性を代表していることが 示された.

以上の結果より, 今回採り上げた pentyl-MMC のように, 脂溶性グループを抗癌剤分子構造中に 導入することにより，特に動注療法などにおける 抗癌郕の腫瘍組織移行性をいちじるしく向上しう ることが示唆されるとともに，本実験系がこうし た DDS アプローチの定量的評価に有用であるこ とが確かめられた.

つぎに, MMC-デキストラン結合体をモデルに 用いて, 本実験系の高分子化プロドラッグ型 DDS

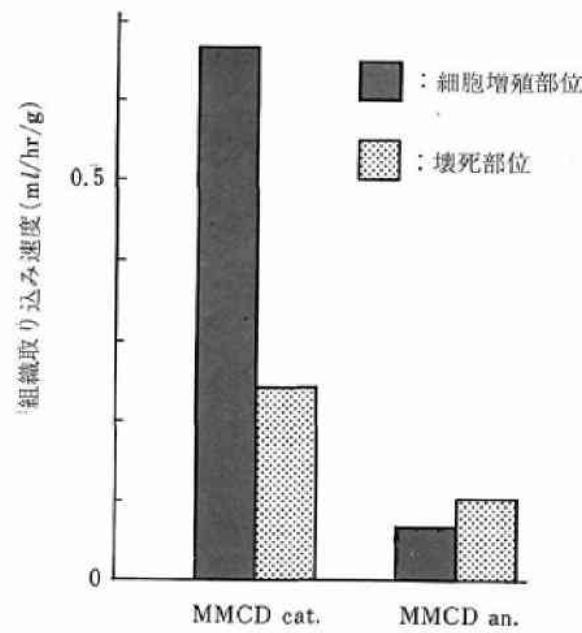

图4 定速注入実験により求めたマイトマ イシンCーデキストラン結合体の湟 韵組緎取り込み速度

の腫瘍組織移行性評価系としての有用性を検討し た．腫瘍標本における高分子物質の毛細血管透過 性はいちじるしくわるく，いずれの高分子化プロ ドラッグでも瞬時投与実験では有意な組織取り込 みは認められなかったので，以下の実験は定速注 入法により行った。定速注入実験終了後, 腫瘍組 織を細胞増殖部位と壊死部位に分別し，おのおの 組織中薬物濃度を定量し, 組織取り込み速度を求 めたところ, 図 4 に示したように, 細胞增殖部に おいて分子全体として正電荷を持つ MMCDcat. の組織取り込み速度は負電荷を持つ MMCDan. の約 10 倍の值を示した.このように高分子化プロ ドラッグが緩除にではあるが腫瘍組織に蓄積する こと,また, 電荷が移行・蓄積に大きな影響を与 えることが示唆され，併せて本実験系を用いた定 速注入実験が高分子性薬物の腫瘍移行性評価の有 用な手段になることが示唆された。

\section{結 語}

ラットに移植した Walker 256 単離腫瘍標本を 用いて，灌流実験系を作成し，薬物を動脈側から 注入後得られる静脈側流出パターンあるいは腫癌 組織内濃度を, 薬動学的に解析することによって, 薬物の腫瘍病巣局所における移行特性の評価が可 能となった,

本実験およびその解析系は，腫瘍組織を標的と 
するターゲティング型 DDS の開発に, 種々の貴 重な情報をもたらすものと思われた。

\section{文 献}

1) Hashida, M. et al. : Role of intramuscular administration of water-in-oil emulsions as a method for increasing the delivery of anticancer agents to regional lymphatics. J. Pharmacokin. Biopharm. 5 (3) : 225-239, 1977.

2) Sasaki, H. et al. : Development of lipophilic prodrugs of mitomycin C. III. Physicochemical and biological properties of newly synthesized alkoxycarbonyl derivatives. Chem. Pharm. Bull. 31 (11) : 4083-4090, 1983.

3) Sezaki, H. et al. : Soluble macromolecular carriers for the delivery of anticancer drugs. Advanced Drug delivery Rev. 3:247-266, 1989.

4) Takakura, Y. et al. : Disposition and tumor localization of mitomycin C-dextran conjugates in mice.
Pharm. Res. 4 : 293-300, 1987.

5) Takakura, Y. et al. : Enhanced lymphatic delivery of mitomycin $\mathrm{C}$ conjugated with dextran. Cancer Res. $44: 2505-2510,1984$.

6) Atsumi, R. et al. : Disposition characteristics of mitomycin $\mathrm{C}$-dextran conjugate in normal and tumor-bearing muscles of rabbits. Cancer Res. $47: 5546-5551,1987$.

7) Gullino, P. M., Grantham F.H. : Studies on the exchange of fluids between host and tumor. I. A new method for growing "tissue-isolated" tumors in laboratory animals. J. Natl. Cancer Inst. 27:679693, 1961.

8) Sevick, E. M., Jain, R. K. : Blood flow and venous $\mathrm{pH}$ of tissue-isolated Walker 256 carcinoma during hyperglycemia. Cancer Res. 48:1201-1207, 1988.

9) Kakutani, T. et al. : A new method for assessment of drug disposition in muscle : Application of statistical moment theory to local perfusion systems. J. Pharmacokin. Biopharm. 13:609-631, 1985. 